\title{
The Implementation of Principle of Justice in Resolving of Consumer Credit Financing Disputes During the Covid-19 Pandemic in Indonesia
}

\author{
Sri Wahyuni ${ }^{1}$, Sufiarina ${ }^{2}$, Fransiska Novita Eleanora ${ }^{3}$, Harinanto Sugiono ${ }^{4}$ \\ \{ sri.wahyuniok31@gmail.com $\left.{ }^{1}\right\}$ \\ Faculty of Law, Universitas Bhayangkara Jakarta Raya, 17121, Indonesia 1,3 \\ Faculty of Law, Universitas Tama Jagakarsa, 12530, Indonesia ${ }^{2}$ \\ Faculty of Law, Sekolah Tinggi Hukum Militer, 13150, Indonesia ${ }^{4}$
}

\begin{abstract}
The Covid-19 pandemic had a major impact on the economy, one of which was in the consumer credit financing sector where a number of people who became debtors experienced difficulties in making installment payments so that they experienced disputes with financing companies. One of them is a case that occurred in Bandung where a twowheeled motor vehicle financing loan debtor who only had $2 \mathrm{x}$ installments left out of a total of 33x experienced difficulties in paying monthly installments because he had not worked due to the impact of the Covid-19 pandemic where in this case the debtor had filed a lawsuit through BPSK Bandung city where the BPSK decision was overturned by the District Court. The problem discussed in this study is how to apply the theory of justice in the settlement of credit financing disputes during the Covid-19 pandemic. This study uses a qualitative method with a case approach and by relating it to John Rawls's theory of justice. The results of this study indicate that the application of the theory of justice in this case is not used as a consideration for court decisions.
\end{abstract}

Keywords: Consumer credit financing, Dispute, Covid-19

\section{Introduction}

The first case of covid-19 in Indonesia was announced on March 2, 2020 [1], since then the number of covid-19 cases has continued to increase and was declared a pandemic by WHO on March 11, 2020 [2]. The government adopted a Large-Scale Social Restriction (PSBB) policy through Permenkes 9/2020 concerning PSBB Guidelines for the Acceleration of Handling COVID-19 which was set in Jakarta on April 3, 2020. The emergence of the Covid-19 Pandemic and the PSBB policy by the government had a significant impact on various sectors, especially in the economic sector. Community income has dropped dramatically because people cannot work as before. Many people who have obligations in credit agreements in banks and in finance companies have difficulty paying their debt obligations, if this happens there will be a lot of bad credit which will threaten the stability of the domestic financial system. Therefore, the government issues relaxation stimulus policy for banking debtors through the Financial Services Authority Regulation (POJK) Number 11 / POJK.03 / 2020 concerning National Economic Stimulus as a Countercyclical Policy on the Impact of the Spread of Coronavirus Disease 2019 and Regulation Number 14 / POJK.05 / 2020 concerning the Countercyclical Policy on the Impact of Coronavirus Spread Disease 2019 for Non-Bank Financial Services Institutions 
(LJKNB). Based on the POJK provisions, it is stated that NBFIs can provide financing restructuring to debtors who are affected by the spread of covid-19.

Various cases of financing disputes began to occur after the emergence of the Covid-19 pandemic, one of which was the financing dispute between Siti Solihat and PT Federal International Finance (FIF) based on decision 336/Pdt.G/2020/PN.Bdg. The background of this case was when Siti Solihat had a consumer financing agreement in the form of motorcycle financing on June 3, 2017 with installments for a period of 33 months, Siti Solihat made 31 months of payments, and then due to the Covid-19 pandemic, Siti Solihat had difficulty making payments. The remaining 2 months of the last installment. As a result of the arrears in installments, Siti Solihat's motorbike that was being driven by her child was stopped in the middle of the road by a third party who claimed to be from FIF and handed over the data of Siti Solihat's motorcycle vehicle precisely with the aim of taking the motorbike because it was still in arrears of payment [9]. Siti Solihat's motorbike and STNK were taken by a third party. According to the third party's information, if the motorbike and STNK want to be returned, please contact the FIF to solve it. However, when Siti Solihat came to the FIF to take care of taking the motorbike pulled by the third party, it turned out that the motorbike was not in the FIF Lembang office and was advised by the FIF to report to the Cinambo Police, Bandung. Then Siti Solihat took this problem to the Bandung Consumer Dispute Resolution Agency. Then the BPSK according to Decision Number 18/G/VII/2020/BPSK.Bdg. August 11, 2020, in the decision stated that the Business Actor, in this case PT. FIF Lembang Branch as Business Actor / Defendant to return the motorbike owned by Siti Solihat as the Consumer / Plaintiff, then Siti Solihat as the consumer / Plaintiff was sentenced to pay the outstanding arrears.

Then the PT. FIF Lembang Branch filed an objection to the Bandung District Court and based on Decision Number 336/Pdt.G/2020/PN.Bdg. and the contents of the decision state that BPSK is not authorized to examine and adjudicate the case and cancel the BPSK decision Number 18/G/VII/2020/BPSK.Bdg. and sentenced Siti Solihat to pay a court fee of Rp. 376,000.

This study uses substantive justice theory in analyzing existing problems. Anwar C [3] said that humans are not perfect in making laws because it requires the ability of judges to interpret laws, therefore judges are encouraged to explore a sense of substantive justice rather than being bound by statutory provisions. Based on this description, the authors are interested in analyzing how is the implementation of principle of justice in the resolving of consumer credit financing disputes during the Covid-19 pandemic in Indonesia.

\section{Method}

This research method uses normative legal research methods with a qualitative approach. This qualitative research method is a research model that comes from social science to examine social problems and phenomena in depth with a relatively small research area or population but focus on data analysis. Conducted qualitatively, namely not using numbers and formulas but focusing on case studies in accordance with court decisions.

According to Soerjono Soekanto [4], research is a scientific activity based on analysis and construction carried out systematically, methodologically and consistently and aims to reveal the truth as manifestation of the human desire to know what it is facing. Then according to Peter Mahmud Marzuki [5], normative legal research is a process to find a rule of law, legal principles, and legal doctrines in order to answer the legal issues faced. In this study, including normative legal research using secondary data in the form of journals, books, court decisions 


\section{Results and Discussion}

The first cases of Covid-19 were found in Wuhan, China in December 2019 [6]. Since then, the Covid-19 cases began to spread throughout the world. As of February 29, 2020, there have been 102 positive cases of Covid-19 in Singapore [7]. Singapore began imposing travel restrictions on China and South Korea. As a result of the Covid-19 pandemic, the economies of these countries are experiencing a decline. China's economic growth fell $-6.8 \%$ in the first quarter of 2020 [8], and Singapore economy down -0.3\%. Indonesia announced the first case of Covid-19 on March 2, 2020 and adopted the Large-Scale Social Restrictions (PSBB) policy on April 3, 2020. The impact of covid-19 on the Indonesian people has occurred since the outbreak of the coronavirus in China in late December 2019 and its economic impact began to wider since March 2019 which caused the Indonesian economy to contracted by $-5.3 \%$ in the second quarter of 2020. Since the Covid-19 pandemic, many consumer financings disputes have occurred.

\subsection{The Dispute Case}

This consumer dispute case appeared at the beginning of the emergence of the Covid-19 pandemic. Siti Solihat has a consumer credit financing agreement with PT Federal International Finance (FIF) in the form of financing for Honda Beat motorbikes in June 2017 for a period of 33 months. Siti Solihat has made 31 installments, but in early 2020 Siti Solihat had difficulty paying the remaining 2 installments due to her job loss due to the Covid-19 pandemic. On June 24, 2020 at around 10:00 WIB in the Cinambo area of Bandung, his son was stopped by two men who claimed to be field officers from the FIF branch of Lembang (Third Party). They asked about the ownership of the motorbike and matched the data they held, the third party said that the motorbike was in arrears in installments, so it had to be withdrawn (confiscated). Finally, the two men took the motorbike along with the STNK by giving a confiscation certificate and asking to hand over the confiscation letter to the Honda Motorcycle Dealer on Jl. Cihampelas Bandung. The third party said that Siti Solihat's motorbike was taken to the FIF Lembang office and waited there and asked to contact Mr. Yogi at the FIF. When Siti Solihat came to the FIF office, Mr. Yogi admitted that he did not know anything about the motorcycle withdrawal and gave a cover letter to the police. Cinambo. Siti Solihat, who did not get a solution to the problem from the Lembang branch of FIF, complained to the Bandung City Consumer Dispute Resolution Agency (BPSK) on July 13, 2020. Siti Solihat and FIF agreed to choose a dispute resolution method through BPSK procedures and convened, but before the trial was concluded, FIF party left the court and did not attend again until the trial was decided by the decision of BPSK Number 18/G/VII/BPSK.BDG. The decision of the BPSK for the city of Banding is as follows:

- State that the Defendant/Business Actor is unable to prove his/her innocence.

- Sentenced the Defendant / Business Actor to return a motorcycle with the HONDA Type Beat Brand, Year 2017, white color, No. Pol. D.6780.AAZ, No. Frame: MH1IFZ112HK817897, No. Machinery: JFZ1E1831363, BPKB and STNK under the name of SITI SOLIHAT, along with the accompanying documents or replacing them with similar items of the same qualification and quality to the Plaintiff; within 14 (fourteen) calendar days from the date of this judgment.

- $\quad$ To punish the Plaintiff / Consumer to pay in arrears that are still due to the Defendant / Business Actor within a maximum period of 14 (fourteen) calendar days from the date of this judgment.

- All costs incurred in the examination of this dispute shall be borne by the State. 
Then, the FIF party filed an objection to the Bandung City BPSK decision to the Bandung District Court.

\subsection{Claims of Petitioners}

The Plaintiff's claim (PT. FIF Cabang Lembang) is as follows:

- Granted all of the objection petitioners' application for objections;

- To declare that BPSK Bandung does not have the authority to adjudicate disputes;

- Declare that the Bandung City BPSK Procedure in this case is invalid so that the Bandung City Consumer Dispute Resolution Agency (BPSK) Arbitration Decision No: 18 / G / VII / 2020 / BPSK. BDG has become legally flawed so it must be declared null and void;

- Declare the Arbitration Decision of the Bandung City Consumer Dispute Resolution Agency (BPSK) No: 18 / G / VII / 2020 / BPSK. BDG in excess of the Lawsuit (Ultra Petitum Partium);

- Declare that the Consumer Financing Agreement No. 301001455417 dated 3 June 2017 between Siti Solihat and PT Federal International Finance is valid and valuable in accordance with the valid terms of the agreement and must be implemented;

- To declare that PT Federal International Finance is not involved and is not responsible for the handover of the HONDA Type Beat Motorcycle, Year 2017, white color, No. Pol. D.6780.AAZ, No. Frame: MH1IFZ112HK817897, No. Machine: JFZ1E1831363, BPKB and STNK on behalf of SITI SOLIHAT carried out by the Respondent's child Objection to an unknown person by PT Federal International Finance;

- Stating that the handover letter or document used by the Respondent for Objection to file a complaint at the Bandung City BPSK is the Official Report on the Settlement of False Financing Liabilities and not an Official Report on the Settlement of Financing Liabilities owned by PT Federal International Finance;

- To punish the Respondent's objection to pay off the remaining debt and a fine due to consumer delay;

- Declare that the Respondent has legally and convincingly manipulated the reality by using a letter or document in the examination which was suspected of being fake, hiding the documents of a decisive nature, and a series of deception related to the case which was decisive in nature;

- Declare the Arbitration Decision of the Bandung City Consumer Dispute Resolution Agency (BPSK) No: 18 / G / VII / 2020 / BPSK. BDG legally flawed and declared null and void or at least completely annulled;

- To punish the Objection Respondent to pay the entire cost of the case in the examination of the objection request at the Special Class IA Bandung District Court.

\subsection{District Court Decisions}

The Bandung District Court Judge decided as follows:

- Granted the objection petitioner from PT Federal International Finance Bandung Branch Objection Petitioner;

- Declare that the Consumer Dispute Resolution Agency (BPSK) is not authorized to examine and adjudicate this case; 
- Canceling the Decision of the Bandung Consumer Dispute Resolution Agency Number 18/G/VII/2020/BPSK.BDG dated 11 August 2020;

- Sentencing the Respondent to Objection (Siti Solihat) to pay the cost of this case in the amount of Rp. 376,000.00 (three hundred seventy-six thousand rupiah);

\subsection{Analysis}

The government has issued relaxation regulations in the credit sector through OJK Regulation (POJK) Number 11 / POJK.03 / 2020 concerning National Economic Stimulus as a Countercyclical Policy on the Impact of the Spread of COVID-19 on March 13, 2020 and POJK Number 14/POJK.05/2020 concerning the Countercyclical Policy on the Impact of Coronavirus Spread Disease 2019 for Non-Bank Financial Services Institutions (LJKNB) on April 14, 2020. From the timeframe from the difficulty of payment from Siti Solihat (Debtor) to the taking of the Debtor's motorcycle by a third party, this is the time span where the Covid-19 spread in the world and the Government's implementing policies through POJK No. 11 and 14 of 2020. Besides that, the debtor has shown good faith by making 31 payments out of a total of 33 installments, so that the Debtor's installment obligation only has 2 installments left. In this case, the debtor is entitled to legal protection and relaxation of relief in paying the remaining installments because he started experiencing problems when the Covid-19 pandemic began. The creditors' action of using a third party to collect the remaining installments is inappropriate during the Covid-19 pandemic and there are relaxation rules from the government. The attitude of the creditor who is not responsible for the taking of the debtor's vehicle by a third party is very detrimental to the debtor because this might not happen if the creditor has good faith in solving the debtor's problem considering the debtor's debt has almost been paid off.

The judge only considers the objection of the creditor regarding the legal standing of the BPSK decision based on consumer financing agreement document number 301001455417 and the existence of a financing agreement according to the validity conditions of the agreement according to Article 1320 of the Civil Code.

The judge did not consider the existence of a pandemic condition that had an impact on the debtor. The judge did not consider the existence of the relaxation policy given by the government through POJK Number 11 and POJK Number 14 of 2020 so that financial service actors provide restructuring for debtors affected by the Covid-19 pandemic. The judge did not consider the payments made by the debtor 31 times and only 2 installments were left. The judge did not consider that a third party took the debtor's vehicle on the road. The judge did not consider the protection of consumer personal data which should be confidential but known in detail by third parties. The judge did not consider the existence of a financing company cooperation with a third party in conducting debt collection.

\section{Conclusion}

It is not easy to translate justice into a judge's decision, in this case the decision has not fully considered substance justice. Fairness of substance that is objective, honest, impartial and rational consideration. Rational means according to reason or can be accepted by common sense.

This justice has not yet been fully realized, especially on the side of consumers who have been affected by Covid-19, the debtor is experiencing difficulties in paying the remaining credit of the last 2 installments and motorcycles that have been taken by third parties and are charged 
with paying court fees. In solving the problem, the parties should have reached a consensus by restructuring the remaining debt so that a win-win solution can be achieved for the parties.

\section{References}

[1] R. Nuraini, "Narasi," Menteri Komunikasi dan Informatika, 2 March 2020. [Online]. Available: https://indonesia.go.id/narasi/indonesia-dalam-angka/ekonomi/kasus-covid-19-pertama-masyarakatjangan-panik. [Diakses 2511 2020].

[2] J. Ducharme, "Health," Time USA, LLC, $11 \quad 3$ 2020. [Online]. Available: https://time.com/5791661/who-coronavirus-pandemic-declaration/. [Diakses 2511 2020].

[3] A. C, "Problematika Mewujudkan Keadilan Substantif dalam Menegakkan Hukum di Indonesia," Jurnal Konstitusi, vol. III, Juni 2010.

[4] S. Soekanto, Penelitian Hukum Normatif, Jakarta: RajaGrafindo Persada, 2015.

[5] P. M. Marzuki, Penelitian Hukum:Edisi Revisi, Jakarta: Prenadamedia Group, 2016.Hootsuite (We are Social). 2020. Indonesian Digital Report 2020

[6] W. H. Organization, “Coronavirus Desease 2019 (Covid-19) Situation Report - 94,” World Health Organization, Jenewa, April 2020.

[7] "News Higlight," Ministry of Health Singapore, 29 February 2020. [Online]. Available: https://www.moh.gov.sg/news-highlights/details/three-more-cases-discharged-four-new-cases-ofcovid-19-infection-confirmed. [Diakses 25 November 2020].

[8] Trading Economics, [Online]. Available: https://tradingeconomics.com/china/gdp-growth-annual. [Diakses 25 November 2020].

[9] Dakum, D., \& Asari, A. (2020). Urgensi Pembentukan Undang-Undang Fintech sebagai Upaya Legalisasi Penyelesaian Sengketa Transaksi Fintech di Indonesia. Borobudur Law Review, 2(1), 115. 